\title{
Seasonal Variation in Resistance of Aspen Stems to Shearing Force
}

\author{
Craig W. M. Dockrill, ${ }^{1}$ Arthur W. Bailey, ${ }^{2}$ \\ Peter V. Blenis, ${ }^{3}$ and Jane R. King ${ }^{4}$ \\ Authors are ${ }^{1}$ Former Graduate Student, ${ }^{2}$ Emeritus Professor, and ${ }^{4}$ Professor Dept of Agriculture, \\ Food and Nutritional Science (AFNS), University of Alberta, Edmonton, Alberta, T6G 2P5, Canada; and \\ ${ }^{3}$ Professor of Forest Pathology, Dept of Renewable Resources, University of Alberta, Edmonton, Alberta, T6G 2H1, Canada.
}

\begin{abstract}
Seasonal changes in aspen (Populus tremuloides Michx.) resistance to shearing force were described to determine their apparent contribution to seasonal changes in cattle utilization. Shearing resistance of current-year, 1-year-old, and 2-year-old stem-age classes were measured from late spring to early fall. For all stem-age classes, resistance to shearing force increased with time, partially due to increasing stem diameter. Depending on stem-age class, resistance to shearing force increased by $200 \%-2000 \%$ between the first and last measurements of a given year. Increased resistance of aspen stems to shearing force in late summer may reduce their selection by cattle. Grazing management that defers cattle entry until midsummer could reduce damage to regenerating aspen associated with cattle foraging in cut blocks.
\end{abstract}

\section{Resumen}

Los cambios estacionales de la resistencia del "Aspen" (Populus tremuloides Michx.) a la fuerza de corte fueron descritos para determinar su contribución aparente en los cambios estacionales de su utilización por el ganado. La resistencia al corte en tallos clasificados como del año en curso y de uno y dos años de edad se midió a fines de primavera e inicios de otoño. En todas las clases de edad de los tallos, la resistencia al corte se incrementó con el tiempo, parcialmente debido al aumento en el diámetro del tallo. Dependiendo de la clase de edad del tallo, la resistencia a la fuerza de corte se incrementó de $200 \%-2000 \%$ entre la primera y última medición en el mismo año. El aumento en la resistencia de los tallos del "Aspen" a la fuerza de corte a fines de verano puede reducir su selección por el ganado. El manejo del apacentamiento que difiere la entrada del ganado hasta mediados de verano podría reducir el daño de las poblaciones de "Aspen” en proceso de regeneración asociadas con el apacentamiento de ganado en áreas en que el "Aspen" fue cortado.

\section{INTRODUCTION}

Trembling aspen (Populus tremuloides Michx.) is an important source of forage for cattle, habitat and forage for wild ungulates, and a major source of fiber for commercial forestry in western Canada (Peterson and Peterson 1992; Bailey 2004). The tender twigs and leaves of aspen stems are acceptable as forage by cattle and wild ungulates, although herbivores avoid larger-diameter twigs (Shipley et al. 1998; Wilson and Kerley 2003).

In boreal and foothill forests, cattle grazing presents management challenges for both timber and livestock producers on recently logged clear-cuts (Navratil 1991). Cattle use aspen as a normal part of their diet in the Aspen Parkland (Hilton and Bailey 1974), with utilization of aspen stems and leaves being greater in June than September (Bailey and Arthur 1985). Similarly, cattle in boreal and foothill cut blocks make the greatest use of aspen stems and leaves in June and July (Lane 1998; Dockrill et al. 2004).

Research was funded in part by Natural Science and Engineering Research Council and Weyerhaeuser Canada Ltd.

Correspondence: Peter V. Blenis, Department of Renewable Resources, University of Alberta, Edmonton, Alberta, T6G 2H1, Canada. Email: peter.blenis@ualberta.ca

Manuscript received 16 March 2005; manuscript accepted 5 December 2005.
Cattle grazing in cut blocks of commercial forests may affect stand regeneration (Dockrill et al. 2004) but less so if grazing occurs later in the growing season (Lane 1998). The reason for decreased impact with time may be related to changes in aspen tissues that increase resistance to browsing. Over the growing season, the production of cells with thicker cell walls likely increases resistance to shearing force. This may result in greater rejection of aspen stems as forage by cattle.

Studies on shearing force resistance and digestibility of several forages may provide insights relevant to aspen. First, increasing resistance to shearing force is correlated with increasing neutral detergent fiber, acid detergent fiber, and lignin (Hughes et al. 2000). These characteristics are associated with decreased forage quality, acceptability, and palatability. Second, voluntary intake by sheep of perennial ryegrass (Lolium perenne L.) accessions selected for high resistance to shearing force was less than that for accessions with low resistance to shearing force (Inoue et al. 1989), suggesting that animals may avoid grazing the former. Third, the force required to shear alfalfa (Medicago sativa L.) stems increased as the season progressed, likely in response to changes in the physical and chemical properties of stems (Iwaasa et al. 1996). Fourth, seasonal changes in resistance to shearing force may result from changes in plant size and cell structure. Whereas changes in shear force adjusted for differences in size may better reflect 

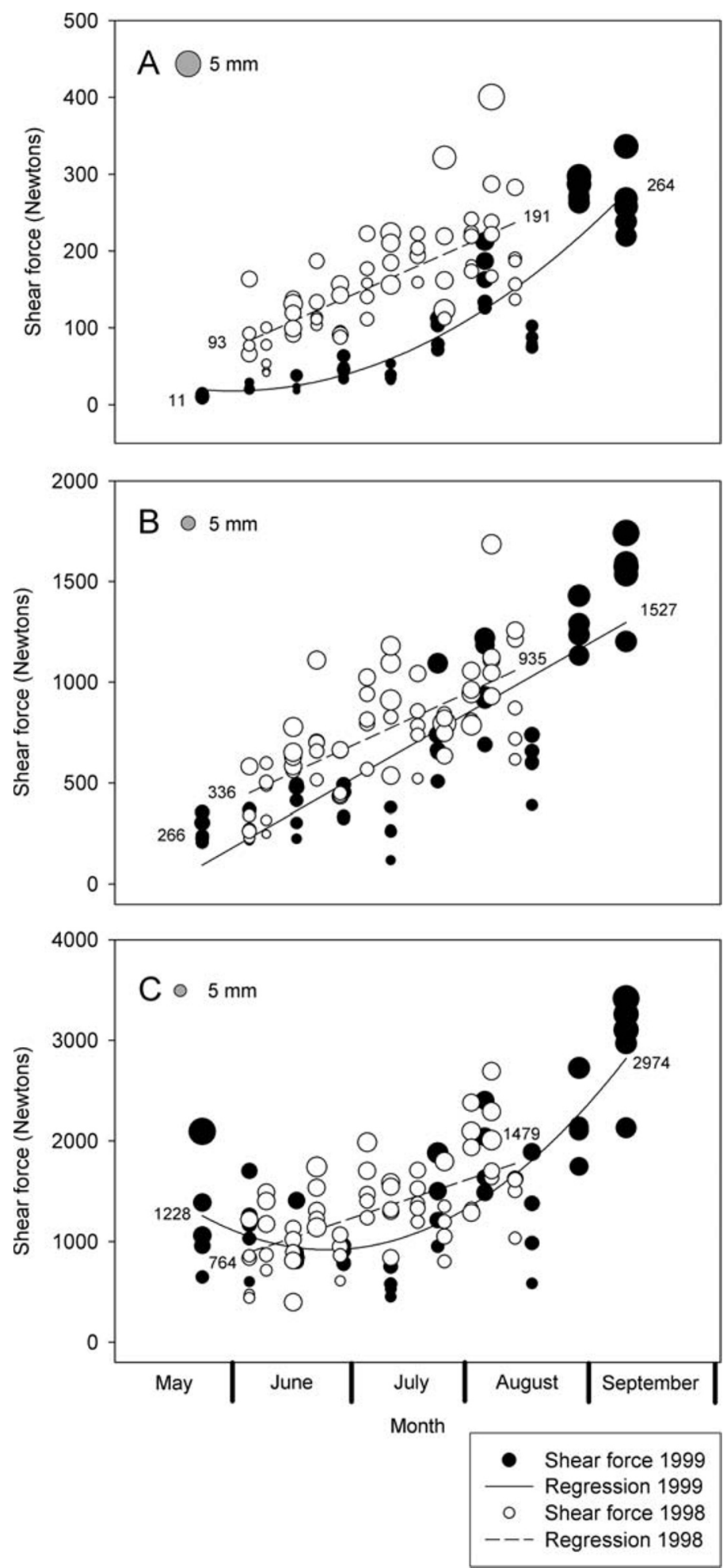

Figure 1. Change over time in the force (in Newtons) required to shear current year's growth $(\mathbf{A})$, one-year-old growth $(\mathbf{B})$, and two-year-old growth (C) produced in 1998 and 1999. The linear relationship between date and shear force was significant in all instances $(P<0.0001)$. There was a significant quadratic trend for current and two-year-old growth in 1999 ( $P=0.049$ and 0.024 , respectively). Symbol diameters are proportional to shoot diameter; a 5-mm scale is shown in the upper left-hand corner of each panel. Average values of initial and final resistance to shearing force are shown at the beginning and end of each regression line. In all cases, model $P$ values were less than 0.0001 . chemical composition and digestibility, the raw, unadjusted shear force values may better reflect the effort required by herbivores to sever foliage (Hughes et al. 2000).

To determine if changes in aspen resistance to shearing force were consistent with a decrease in browsing injury over the growing season, the resistance to shearing force of current year's growth, 1-year-old growth, and 2-year-old growth were evaluated. The first objective was to evaluate how aspen resistance to shearing force changed over the growing season. The second objective was to partition such changes into 2 components: 1) the indirect increase in shear force as a consequence of increased shoot diameter with date, and 2) a direct association between date and shear force, above and beyond the effects of diameter changes over time.

\section{METHODS}

Five sites, within a radius of about $3 \mathrm{~km}$, in 2 different cut blocks were selected near Nojack Alberta in the Lower Boreal Cordilleran (LBC) ecozone (Beckingham et al. 1996). All were regenerating to aspen, following clear-cutting in the late summer of 1994 . Four stems were collected per site at 7-day intervals between 9 June and 27 August 1998 and at 14-day intervals between 26 May and 29 September 1999. All trees were at least 2 years old, $80 \mathrm{~cm}$ tall, and free of injury. Each stem was partitioned into 3 stem-age classes (current, 1-yearold, and 2-year-old portions) based on bud scar location.

Shoot diameter at the midpoint of each stem part was measured, and the force required to shear the shoot at that point was determined with the use of an Instron-1000 (Instron Corporation, Canton, MA). The instrument was modified to include both a metal block with a $2.5-\mathrm{cm}$-diameter hole that held the stems in position, and a $0.6-\mathrm{cm}$ blunt blade that sheared the specimens. Computer-generated graphs of applied force quantified the force necessary to shear the stems.

Measurements of shear force and diameter were averaged over the 4 sample stems for each combination of site, time of year, and stem-age class. Analysis was done separately for the 3 stem-age classes and 2 years (separate analysis by years was necessitated by the statistical interaction between year and time of year). Two statistical analyses were conducted. First, analysis of covariance, followed by trends analysis (Steel et al. 1996) was used to determine if there were linear or quadratic temporal trends in the shear force required to sever stems, following adjustment for stem diameter.

Second, path analysis ( $\mathrm{Li}$ 1977) was used. Based on principles of multiple regression, path analysis determines the relative strength of different pathways between several related independent variables and a dependent variable. In this case the relationship between date and shear force was partitioned into 2 components: the direct effect of date on shear force (likely occurring because of changes in cell structure and chemistry), and the indirect effect that was mediated through diameter (because resistance to shearing would increase with stem diameter).

\section{RESULTS}

Less force was required to shear aspen shoots of current growth (Fig. 1A) than 1-year-old shoots (Fig. 1B), and still more force 
was required to shear 2-year-old shoots (Fig. 1C). There was some increase in shear force between growing seasons; on 27 August 1998, the current year's growth had an average shear force of 191 (95\% confidence interval, \pm 69 ) Newtons (N) and on 26 May, 1999, 1-year-old growth had a shearing force of 266 ( \pm 76$)$ N. Similarly, the shearing force for 1-year-old shoots at the end of 1998 and 2-year-old shoots at the beginning of 1999 were $935( \pm 359)$ and $1228( \pm 683)$ N, respectively (Fig. 1).

There was a considerable increase in resistance to shearing force as the growing season progressed from spring to fall. Depending on stem age class and year, estimated resistance to shearing force increased by 200 to $2000 \%$ between the first and last measurements (Fig. 1). Analysis of covariance demonstrated that 1) the linear increase in shear force with time was highly significant $(P<0.0001)$ for all years, 2$)$ the quadratic effect was significant only for current and 2-year-old stems in 1999 $(P=0.049$ and 0.024 , respectively $)$, and 3$)$ diameter was a significant covariate $(P<0.0001)$ in all cases except for 2 -yearold stems in $1998(P=0.093)$. Taken together, these results indicate that although shear force increased with diameter, there was a very strong tendency for shear force to increase over time, even after accounting for the effect of increased shoot size.

Path analysis indicated that the relationship between diameter, date, and shearing force varied with year. In 1998, the direct effect of date was quite large, whereas the indirect effect of date, mediated through increased diameter, was considerably smaller (Fig. 2). In 1999, the reverse was true; most of the association between date and shearing force could be accounted for by the increase in diameter over the growing season.

\section{DISCUSSION}

In 1999, sampling was performed over a longer period of the growing season (to capture changes in stem resistance during September) with longer intervals between consecutive sampling dates. Both the interaction between the effects of year and time of year on shearing force as well as the path analysis indicated significant interyear variability, which may have occurred because of different weather conditions in the 2 years.

Results from this study provide one explanation as to why early-season cattle grazing would be more detrimental to aspen regeneration than late-season grazing (Lane 1998; Dockrill et al. 2004). The force needed to shear 1-year-old and 2-year-old aspen stems is such that those shoot portions would not likely be palatable to cattle at any time. In contrast, in June and early July, current-year aspen shoots would be abundant and would have low resistance to shearing force, making them easy to sever and digest. Growth of herbaceous forage in the Lower Boreal Cordilleran ecozone does not reach full capacity until mid-July (Lane and Willoughby 2000). Thus, heavy browsing of aspen might be expected early in the growing season when resistance of current shoots to shearing force is less than approximately $100 \mathrm{~N}$ (Fig. 1A). As the season progresses from spring to summer, herbaceous forage becomes more plentiful (Lane 1998) and aspen stems become less likely to be foraged (Dockrill et al. 2004). These seasonal changes likely explain why cattle shift from utilizing aspen to grazing mostly grasses and forbs, thereby reducing aspen injury.

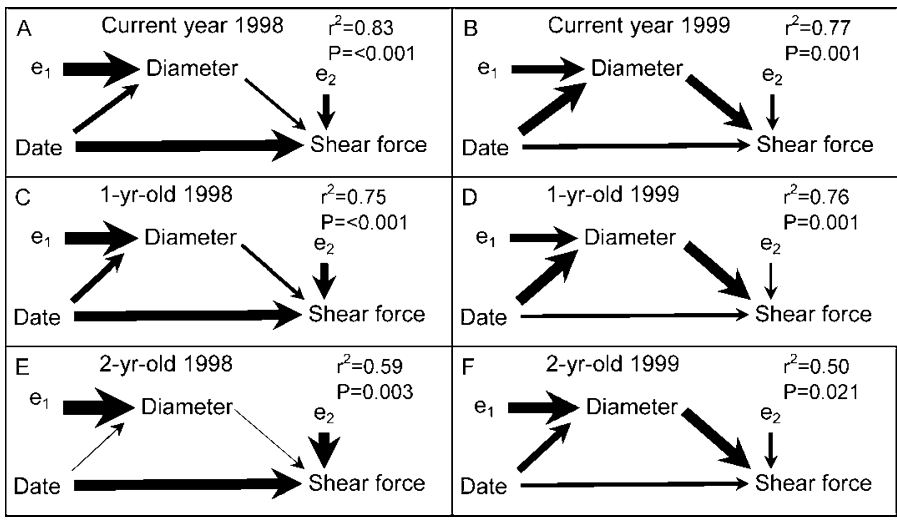

Figure 2. Path analysis of direct and indirect effects of date on shear force for three different stem-age classes in 1998 and 1999, together with the squared correlation coefficient (and $P$ value) between date and shear force. The path model assumed that stem diameter was determined by date and other unknown factors $\left(e_{1}\right)$ and that shear force was determined by the direct effects of date (separate from the indirect effect mediated through diameter), diameter, and other unknown factors $\left(e_{2}\right)$. Arrow widths are proportional to path strength.

In summary, an apparatus was developed to measure aspen resistance to shearing force and was used to determine which portions of aspen stems were likely to be foraged by cattle. Aspen resistance to shearing force increased greatly over the growing season, partly because of an increase in stem diameter and partly because of changes in addition to diameter. Temporal changes in resistance to shearing force and forage availability may explain why spring and early-summer cattle grazing in commercial cut blocks can be more detrimental to aspen regeneration than late-season grazing.

\section{MANAGEMENT IMPLICATIONS}

Knowledge of seasonal and stem age class variation in aspen resistance to shearing force provides further information for the development of grazing management systems that balance the fiber-regeneration needs of timber producers with forage supply needs of cattle producers. Two options for facilitating aspen regeneration without eliminating cattle grazing are 1) a 2 -year absence of cattle grazing in aspen cut blocks following harvest, or 2) a late-May to mid-July deferment of cattle grazing followed by light stocking rates for 3 years postharvest. Both of these strategies are supported by the results of this study and would enhance aspen regeneration without eliminating cattle grazing.

\section{ACKNOWLEDGMENTS}

The authors thank Erin Dale, Bernie Faulkner, and Ian Buttar for designing the device for testing resistance to shearing force.

\section{LITERATURE CITED}

BAlLEY, A. W. 2004. Brush management research on the Canadian Northern Great Plains and adjacent boreal forest. Available at: www.foragebeef.ca. Accessed 22 September 2005 
Balley, A. W., And R. L. Arthur. 1985. Cattle use of aspen suckers encroaching into native fescue rangeland. In: Agriculture-Forestry Bulletin, Feeder's Day Report. Edmonton, Canada: University of Alberta. p 83-84.

Beckingham, J. D., I. G. W. Corns, and J. H. Archibald. 1996. Field guide to ecosites in west-central Alberta. Edmonton, Canada: Forestry Canada, Northwest Region. Special Report 9. 540 p.

Dockrill, C. W. M., P. V. Blenis, A. W. Bailey, and J. R. King. 2004. Effect of summer cattle grazing on aspen stem injury, mortality and growth. Forestry Chronicle 80:257-261.

HILton, J. E., AND A. W. BAILEy. 1974. Forage production and utilization in a sprayed aspen forest in Alberta. Journal of Range Management 27:375-380.

Hughes, N. R. G., C. Borges do Valle, V. Sabatel, J. Boock, N. S. Jessop, and M. Herrero. 2000. Shearing strength as an additional selection criterion for quality in Brachiaria pasture ecotypes. Journal of Agricultural Science 135:123-130.

InOUE, T., I. M. Brookes, T. N. BarRY, and A. John. 1989. Effects of selection for shear strength on the voluntary intake and digestion of perennial ryegrass fed sheep. Proceedings of New Zealand Society of Animal Production 49: 221-224.

Iwaasa, A. D., K. A. Beauchemin, J. G. Buchanan-Smith, and S. N. Acharya. 1996. Effects of stage of maturity and growth cycle on shearing force and cell-wall constituents of alfalfa stems. Canadian Journal of Animal Science 76:321-328.
Lane, C. T. P. 1998. Effect of full-tree skidding and livestock grazing on aspen regeneration [dissertation]. Edmonton, Canada: University of Alberta. $134 \mathrm{p}$.

Lane, C. T., And M. G. Willoughby. 2000. Forage growth of deciduous communities in northern Alberta. In: 53rd Annual Meeting, Society for Range Management; 13-18 February; Boise, ID. 2 p.

LI, C. C. 1977. Path analysis-A primer. Pacific Grove CA: Boxwood Press. 347 p.

NavratiL, S. 1991. Regeneration challenges. In: S. Navratil and P. B. Chapman (EDS.) Aspen management for the 21st century. Symposium Proceedings; November 20-21, 1990. Edmonton, Canada: Northwest Region, Northern Forestry Centre and Poplar Council of Canada. p 15-27.

Peterson, E. B., and N. M. Peterson. 1992. Ecology, management, and use of aspen and balsam poplar in the prairie provinces. Edmonton, Canada: Forestry Canada, Northwest Region. Special Report 1. 252 p.

Shipley, L. A., S. Blomquist, And K. Danell. 1998. Diet choices made by free-ranging moose in northern Sweden in relation to plant distribution, chemistry and morphology. Canadian Journal of Zoology 76(9):1722-1733.

Steel, R. G. D., J. H. TorRie, And D. A. Dickey. 1996. Principles and procedures of statistics: A biometrical approach. 3rd ed. New York: McGraw-Hill. 666 p.

Wilson, S. L., and G. I. H. Kerley. 2003. Bite diameter selection by thicket browsers: the effect of body size and plant morphology on forage intake and quality. Forest Ecology and Management 181:51-65. 